取材レポートーマーケティング・エクセレンスを求めて 109

\title{
「おもてなし」で競争優位性を築く海外展開
}

一株式会社ファミリーマートー

京都大学大学院 経営管理研究部 特定講師

\section{鈴木 智子}

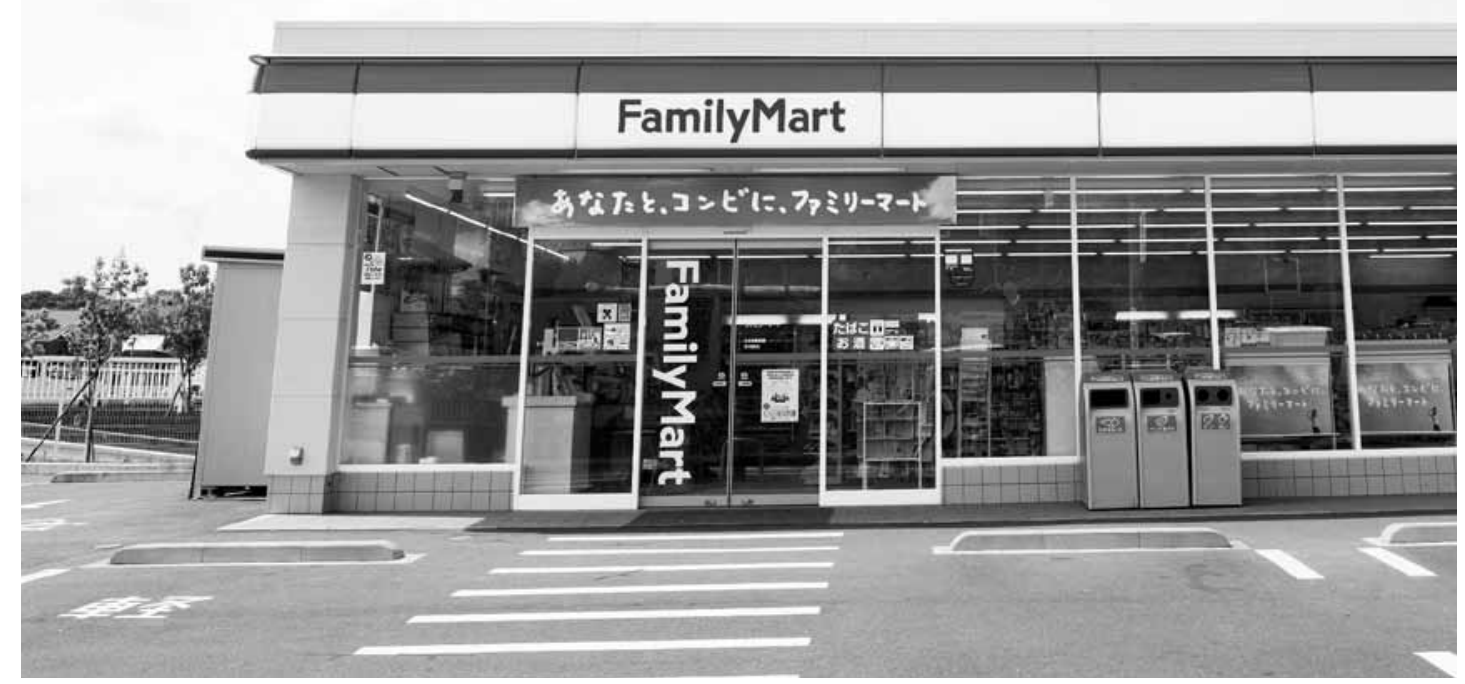




\section{I . はじめに}

「国は変わっても，言葉は違っても，お 客さまを自分たちの家族のようにお迎えす る，私たちのおもてなしは変わりません。 日本発のコンビニとして, 台湾, タイ, 中国, アメリカ, ベトナム, インドネシア, フィ リピンへ。世界に広がるファミリーマート に, どうぞご期待ください。」(株式会社ファ ミリーマートのホームページより）

2013年, 株式会社ファミリーマート (以下ファ ミリーマート）は, ASEAN主要国の中でも高 いGDP成長率を誇るフィリピンに進出した。 高級感のある椅子やテーブルを設置し, SQC （サービス，クオリティ，クリンネス）を徹底 した。常にきれいで高級感あふれる店内, そし て店員による明るくスピーディーでホスピタリ ティあふれる温かい接客など，日本流のおもて なしを展開し，競合と差別化を行った。「ここ はいつもきれいだし，店員さんがとても親切。」 「居心地がいい。」フィリピンの客からは, この ような声が聞こえた。

フィリピンは, ファミリーマートにとって 8 力国・地域目の海外進出先となる。1988年に 台湾に進出して以来, 同社は積極的に海外展開 を進め, 2009年には日本発祥のコンビニエンス・ ストア・チェーン(以下コンビニ)として初めて, 海外店舗数が国内店舗数を上回った。2013年 度末時点には, アジアを中心に 8 力国・地域で 23,622 店舗を展開し，店舗数において世界第 2 位であった ${ }^{1}$ 。このファミリーマートの海外展 開の成功の背景には, 日本で培った, 商品開発
や店舗運営のノウハウ, 物流, IT システムなど, コンビニのビジネスモデルによるものが大きい が，それとともに，おもてなしの活用による部 分も大きい。同社のグローバルブランディング を担当している総合企画部のマーケティング室 長，岩崎浩は次のように述べている。

まず国内の中でも，コンビニの店舗数は 5 万店を超えています。これだけ嬂烈な競争 になってくると，最後はやっぱり人的サー ビスに帰結すると思うんです。スーパー マーケットのレジでは, 店員さんと顔見知 りになって，会話をするというシーンはな かなか見かけないですよね。そういうなか で，カウンターでサービスを行えるという のは、コンビニの強みだと思うんです。 最初は何気なく, パンや牛乳を買いに行っ てたのが、「ああ, デザートもあるみたい。 和菓子もあるみたい。」「また，お店の人 が良い人でね。」みたいな感じのつながり が，ほんの些細なことなんですけど，それ が日々お客さまと行われますと，大変なコ ミュニケーションの数になっていくんです ね。

グローバルの場合にも我々は，やはり日本 流のおもてなしを海外にも輸出していきた いっていう風に思っています。

近年, 日本流のおもてなしを武器に, 海外で ビジネスを展開しょうという動きが広がりつつ ある（NHK, 2010）。競争が厳しいグローバル 市場では，商品の良さだけでなく，客に感動を 与えられる会社であることが，差別化の要因に なりうるからだ。しかし，おもてなし精神に 
は日本独自の文化的背景があり（五嶋・中村， 2009），日本人にとっては暗黙知だが，異文化 で育った人間にはピンとこない。文化や商習慣 が異なる環境で，おもてなしを展開するのはな かなか難しい。ではファミリーマートはいか にして，海外で抒もてなしを展開することに成 功したのであろうか。本稿では，「おもてなし の標準化」「おもてなしの脱属人化」「おもてな し啓蒙者の開拓」「おもてなし文化の醸成」「お もてなし人材の育成」といった，おもてなしの
海外展開を支えると考えられる5つの仕組みを ファミリーマートの事例を通じて分析し，国際 マーケティングのエクセレンスを探っていきた い。

\section{II . ファミリーマートの沿革と概要}

\section{I. ファミリーマートの沿革}

ファミリーマートは, 1972年に株式会社西 友ストアー（以下，西友ストアー）の企画室に

図表一| ファミリーマートの営業総収入と営業利益の推移 (2005年度〜 2014 年度)

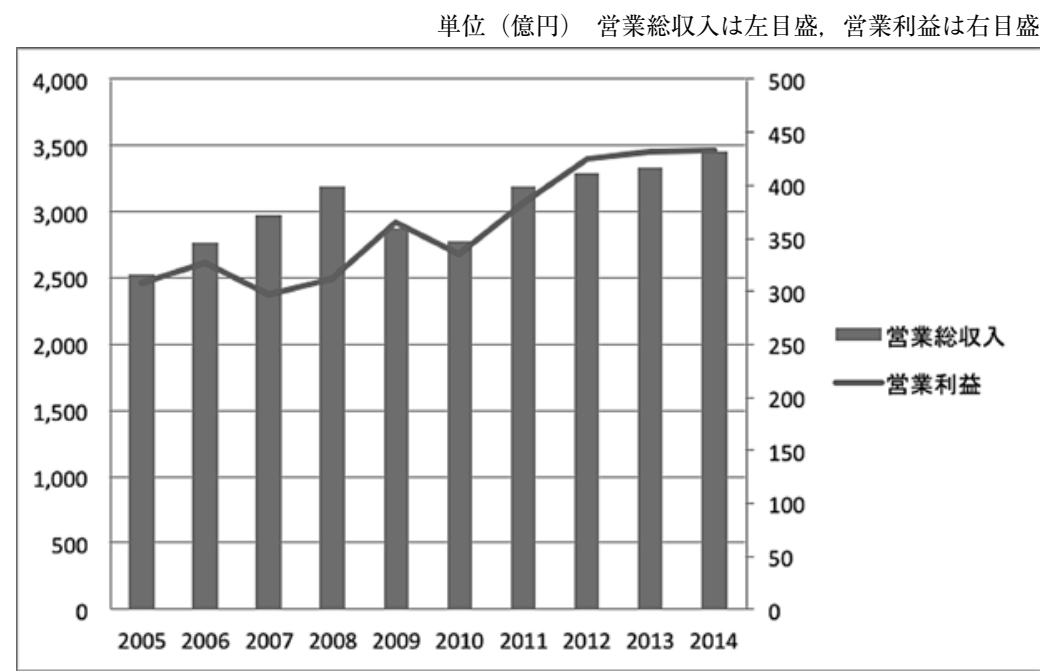

出典：株式会社ファミリーマート『アニュアルレポート 2014』p. 8 ををに作成

図表一2 主要コンビニチェーンの全店売上高（単体）推移（2008 年度〜 2014 年度)

（単位：10億円）

\begin{tabular}{|c|r|r|r|r|r|r|r|}
\hline & 2008 & 2009 & 2010 & 2011 & 2012 & 2013 & 2014 \\
\hline セブン・イレブン & 2,574 & 2,762 & 2,784 & 2,947 & 3,280 & 3,508 & 3,781 \\
\hline ローソン & 1,402 & 1,506 & 1,472 & 1,502 & 1,621 & 1,693 & 1,758 \\
\hline ファミリーマート & 1,121 & 1,245 & 1,273 & 1,440 & 1,534 & 1,584 & 1,721 \\
\hline サークルKサンクス & 860 & 890 & 852 & 855 & 896 & 878 & 895 \\
\hline
\end{tabular}

出典：株式会社ファミリーマート『アニュアルレポート2014』p. 80 
小型店担当が設置されたことに始まる。1973 年 9 月に，実験第 1 号店が埼玉県狭山市に開店 された。その後1981年 9 月に, 西友ストアーか ら営業と資産の譲渡を受け, 商号を「ファミリー マート」に変更して事業が開始された。1987 年 2 月に国内 1,000 店を突破して以来, 株式会 社セブン -イレブン・ジャパン（以下，セブン イレブン) と株式会社ローソン (以下, ローソン) に続く，業界3位のプレーヤーとして，日本の コンビニ市場を牽引してきた。図表ーリにファミ リーマートの営業総収入と営業利益の推移, 図 表-2に主要コンビニチェーン全店売上高(単体) の推移を示した。

日本のコンビニ市場は, 長時間営業, ワンス トップ・ショッピングという高い利便性, 消費 者のニーズに合わせた商品開発, 品揃えのよさ, フランチャイズ・システムによる大量出店で, 1974年にセブン -イレブンが日本に上陸して以 来，高成長を遂げてきた（図表-3に小売業の 売上高推移を示した)。熾烈な競争の下, 各社 は「日本型コンビニ」と呼ばれるビジネスモデ ルを洗練させ，さらには革新的な質の良さを生 み出し, 差別化を図ってきた。プライベートブ ランドなどの商品開発を追求するセブン -イレ ブン, 「ナチュラルローソン」や「ローソンス
トア100」など店舗フォーマットのバラエティ 化を図るローソン，そして店舗の質を高めて社 会・生活インフラ企業を目指すファミリーマー ト，と整理することができる。

海外戦略でも, 3 社の取り組みは微妙に異な る。ファミリーマートの基本戦略は, 現地企業 との合弁会社による市場開拓である（後に詳し く触れる)。ファミリーマートは，自ら出資す ると同時に, 人材を派遣し, 経営分析や営業計 画, 各種マニュアルの整備, 出店計画や出店制 度構築, 商品開発, 物流インフラ構築, ならび に情報システムのノウハウを提供する。一方, セブン -イレブンの海外展開の中核を担うのは, 米国の 100\%子会社である。同社を通じて, 海 外の現地企業にライセンス供与を行っている。 日本の人材を派遣していない国も多く, アジア に日本のノウハウを移管するにも難しさがあ る。そしてローソンは, 現地運営会社の資本の 過半を握る戦略を採っている。日本のノウハウ を移管しやすく，迅速な意思決定もできるが， 店舗数が少ない時点では赤字である。3社のう ち, ファミリーマートの海外収益の成長率は著 しく（2013年 2 月期に海外で稼いた経常利益は 前期比 $14 \%$ 増の 49 億円で, 全体の 1 割強に上っ た),「アジアではファミマの利益拡大が最も期

図表一3 小売業の売上高推移（2008 年度〜 2014 年度)

(単位：10億円)

\begin{tabular}{|c|r|r|r|r|r|r|r|}
\hline & \multicolumn{1}{|c|}{2008} & \multicolumn{1}{|c|}{2009} & \multicolumn{1}{c|}{20 I0 } & \multicolumn{1}{c|}{20 II } & \multicolumn{1}{c|}{20 I2 } & \multicolumn{1}{c|}{20 I3 } & \multicolumn{1}{c|}{20 I4 } \\
\hline 小売業全体 & 136,174 & 134,784 & 134,097 & 135,564 & 136,709 & 137,184 & 141,136 \\
\hline 百貨店 & 8,429 & 7,844 & 7,054 & 6,727 & 6,723 & 6,649 & 6,892 \\
\hline スーパー & 12,824 & 12,815 & 12,513 & 12,852 & 12,978 & 12,905 & 13,250 \\
\hline コンビニ & 7,516 & 8,056 & 7,938 & 8,266 & 8,976 & 9,542 & 10,017 \\
\hline
\end{tabular}

出典：株式会社ファミリーマート『アニュアルレポート2014』p. 80 
待できる」といった評価もみられた（『日経ヴェ リタス』2012年4月22日)。図表-4に，3社の 海外事業の比較をまとめた。

\section{2. ファミリーマートのおもてなし精神}

ファミリーマートは, 一人ひとりの客とのつ ながりを大切にする「高質接客」に取り組んで いる。2005年度より「あなたと, コンビに, ファ ミリーマート」というスローガンを揭げ, 以来, 「ホスピタリティあふれる行動を通じて，客に 『気軽にこころの豊かさ』を提案し, 快適で楽 しさあふれる生活に貢献」することを目指して いる。従来のコンビニではホスピタリティとい う概念は考えられず，コンビニのスタッフが笑 顔で声をかけるということはみられなかった (『週刊ダイヤモンド』2009年1月31日)。しか しファミリーマートでは,「ホスピタリティの ある店づくり」を徹底してきた。

ファミリーマートのサービス重視は, 小売業 の原則といわれるクオリティ $(\mathrm{Q})$ ，サービス (S)，クリンネス（C）の順番にも表れている。 一般的には「QSC」という順にいうことが多い
が, 同社ではあえて「S」を前に持ってきており， $\lceil\mathrm{SQC} 」 と$ 呼んでいる。さらに, SQCはあくま でも小売業を営む上での基本と捉え,ここに「木 スピタリティ（おもてなしの気持ち）」を付加 することを全社員，加盟店に説いている（図表 $-5)$ 。

おもてなしビジネスの特徴の一つとして,「顧 客を『自分にとって大切な存在』と捉え, 自発 的に顧客のニーズを探り, 顧客の期待（水準も しくは範囲）を越えるサービスを提供しようと する姿勢があること」(山口, 2014)がある。ファ ミリーマートは，客のファミリー(家族) のよ うな存在になることをめざして，単に客からの 要望に応えるのではなく, 何が客の喜びにつな がるかを考え, 高品質の価值を提供することを こころがけている。

ホスピタリティを社員一人ひとりに浸透させ る上で重要な役割を担っているのが,「ファミ マシップ」と呼ばれる行動指針である。ファミ マシップは，「お客さまの期待を超えよう」「仲 間を信じ，ともに成長しょう」「豊かな感性を 磨こう」「挑戦を楽しもう」「世の中に向かって

図表一4 大手コンビニ 3 社の海外事業の比較（2012 年 2 月期）

\begin{tabular}{|c|c|c|c|}
\hline & ファミリーマート & セブンイレブン & ローソン \\
\hline 海外店舗数 & 11,245 & 30,960 & 370 \\
\hline 海外店舗の比率 & $56 \%$ & $69 \%$ & $3 \%$ \\
\hline 海外損益 & 43億円 & 327 億円 & 赤字（非開示） \\
\hline 連結利益に占める割合 & $10 \%$ & $11 \%$ & 非開示 \\
\hline 海外運営会社との資本関係 & $\begin{array}{l}\text { 直接出資だが, 大半が } \\
50 \% \text { 未満 }\end{array}$ & $\begin{array}{l}\text { 北米は } 100 \% \text { 出資, 中 } \\
\text { 国の一部は子会社。他 } \\
\text { は北米子会社がライセ } \\
\text { ンス供与 }\end{array}$ & $\begin{array}{l}\text { 大半が直接出資で, 日 } \\
\text { 本側が過半を握る }\end{array}$ \\
\hline
\end{tabular}

出典：『日経ヴェリタス』 2012 年 4 月 22 日, p. 16 
正直でいよう」という5 項目から成るもので, 自ら気づき，感じ，行動を起こしていく接客を 目標とした。

ファミマシップ導入後，それぞれの店で「ホ スピタリティのある店づくり」が実現した。た とえば，長距離トラックドライバーの客が多い 店では，真夏の暑い時期に冷たいおしぼりを， 寒い冬には温かいおしぼりを無料で配り，「気 をつけていってらっしゃい」と声がけをしてい る。他にも, 病院前の店では車いすの来店客向 けにブザーを設置したり，子連れ客が多い店で は幼児用の買い物かごを置いたりしている。こ うした試みはリピーターが増えるなどの好反応 につながり，2008年 2 月期には，コンビニ大手 で唯一, 全月の実質的な既存店売上高がプラス に転じたという結果ももたらした（『日経流通
新聞』2008年 4 月 21 日)。

しかし，こうしたおもてなしの行動は，日本 人的な精神性が求められることが多い。それは, おもてなしが，もてなされる者に直接的にはそ の対価を要求しない「無償」の行為であり, 人 を喜ばせたいという「こころ」であるためだ。 とくに海外では，サービスは必ずしも無償では なく，客はある一定の対応を受けるためにサー ビスチャージやチップといった報酬を支払って いる。ゆえに，海外でおもてなしを展開するの には困難が伴う。では，ファミリーマートはど のようにおもてなしを海外で展開し，それを競 争の優位性とすることに成功しているのだろう か。次のセクションで, 同社のおもてなしの海 外展開の仕組みを分析し，探っていく。

\section{図表一5ファミリーマートにおけるSQC とホスピタリティの関係}

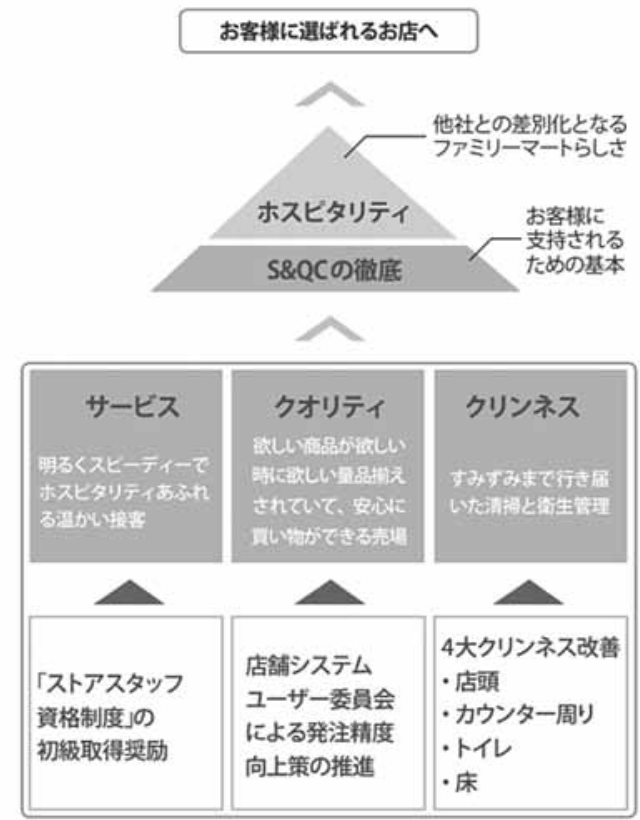



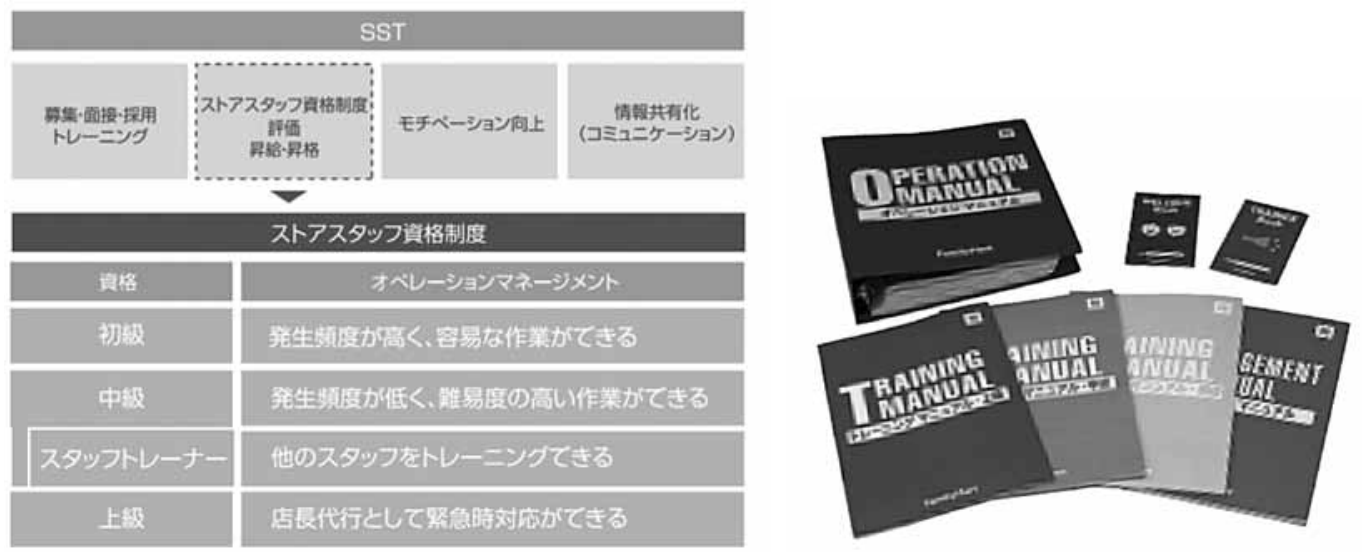

出典：株式会社ファミリーマート『アニュアルレポート2008』p. 51,『アニュアルレポート 2001』p. 7

\section{III. ファミリーマートにおける，}

\section{おもてなしの海外展開}

\section{I. おもてなしの標準化 : マニュアル化}

おもてなしは，従業員の個人芸と考えられる ことが多い。客一人ひとりに合った対応するの がおもてなしだが，客は十人十色であるため, マニュアル化が難しいと思われているためだ。 たしかに，旅館などを考えると，女将や仲居の 性格や技量で，おもてなしの質が決まっている ように感じられる。しかし, 事業の拡大や海外 展開を行う上では，おもてなしを「再現」する 必要がある。ファミリーマートでは，おもてな しをあらゆる場所で，そしてあらゆる人で再現 するために, その標準化を行っているといえる。 その取り組みのあらわれの一つが, 同社の「ス トアスタッフトータルシステム (SST)」である。 この仕組みは, 海外展開時に, ファミリーマー トがコンビニビジネスのノウハウとして，合弁 会社に提供しているものの一つである。
SST とは, 店舗運営のマニュアルである ${ }^{2)} 。$ 店長・トレーナー・一般スタッフといった役割 別のマニュアル，新人アルバイト向けの店内 ルールを示した簡単な入門書, そしてトレー ナー心得本の 5 種類で構成される（図表-6）。 接客やサービスを含めた店内業務に関するマ ニュアルで, 基本動作が詳細に書かれている。 ストアスタッフの生産性と品質向上を体系的に 罒ることを目的とした。SSTの作成に向けては, アルバイト 700 人に意識調査を行ったり，実際 に行われている作業のやり方を 7 店舗で 1 週間 分を収集したりして，現場の視点が重視された (『日経流通新聞』2000年 3 月 23 日)。

SST は, ストアスタッフを「集め」「育み」「や る気を伸ばし」「報いる」ことを主眼とした体 系的なプログラムで，作業手順を統一し，また ストアスタッフの作業全般に対する責任感を醸 成する。例えば，SSTの導入によって，トレー ナーによるスタッフの指導内容や教え方が統一 された。またSSTを通じて, サービス水準の 
向上が実現可能となった。さらに，ストアス タッフはSSTの過程で発注のノウハウも学ぶ が，発注の分担化によってさまざまな情報が集 積され，客のニーズに迅速・的確に対応できる ようになった。その結果，ストアスタッフの積 極性や責任感が高まるという相乗効果も生まれ るようになったという。

ベトナムでの合弁会社の社長を経験し, 現在, ファミリーマート上席執行役員の海外事業本部 長補佐（兼）海外事業部長である山下純一は, マニュアルの意義について次のように述べている。

マニュアルは必要だと思いますね。マニュ アルがあることで, 均質なサービスが提供 できるようになります。(中略）後, 基本 的に, お客さまに対する接客（おもてなし） については，ある程度店の作業に余裕が出 てこないと，ある程度なんの躊躇もなくい ろんな作業できるようにならないと，提供 できないです。レジ打つ時に，緊張しなが らやっていると余裕無いですよね。間違え てしまう。そういったことが当たり前にで きると,レジを打ちながら話もできるで しょうし。だから，基本動作をしっかりと 身に付けるのは大切です。

要するに, マニュアルの存在により, 客は最低 限のサービスを，いつでもどこでも受けられる のである。また山下は, おもてなしもある程度 はマニュアル化できるという。

例えば，日本の航空会社のフライトアテン ダント（客室乗務員）の方が, 日本に帰つ てきたときに「お州りなさいませ」と声を
かけてくれると，心和みますよね。これ， マニュアルなんですけど， ジーンってきま すよね。そういったように，ホスピタリ ティはある程度マニュアル化できると思い ます。

ファミリーマートは, マニュアルをうまく活用 することで，おもてなしの標準化に成功してい るのである。

\section{2. おもてなしの脱属人化 : システム化}

おもてなしというと, 従業員に依存すると考 えられることが多い。もちろん，おもてなしを 提供する上で，人が果たす役割は大きく，それ はファミリーマートでも例外ではない。しかし 同社では,「ホスピタリティのある店」を作る ために，従業員に依存せずともおもてなしを展 開できるシステムを構築している。そしてこの システム構築のノウハウを, 海外の合弁会社に も提供しているのである。これが，同社がおも てなしを海外で展開することに成功した要因の 一つである。

コンビニに求められる基本的かつ最も重要な サービスは, 客が欲しい商品が, 欲しい時間帯 に, 欲しい数量, 品揃えされていることである。 ファミリーマートでは, こうした客のニーズに 応える売場づくりを徹底するために，ストアス タッフの能力や経験だけに頼るのではなく, さ まざまなシステムを構築し, 導入している3”。 その例の一つが,「補充推奨発注システム」で ある。販売動向と在庫数から, 個店ごとの最適 な発注数を自動で計算するシステムである。こ のような自動化された店舗システムの導入で, 長年の経験があるストアスタッフ不在の新店舗 
でも，発注精度を上げ，また個店の特性に適し た品揃えを可能としている。

おもてなしに限らないが，サービスは全般的 に優秀な従業員とそうでない従業員の間で，そ の質にバラつきが生じてしまう可能性がある。 このバラつきが大きくなればなるほど，拡大化 や国際化の際，大きい負の影響が出てきてしま う。ゆえに，拡大化や国際化を検討する企業に とっては, サービスの質のバラつきをいかに低 下させるかといったことが, 重要な課題となる。 ファミリーマートは, 海外の合弁会社にも, POSをはじめとした情報システムのノウハウ を導入している。そして，ストアスタッフのレ ベルに左右されることなく，「お客さまの欲し い時に，欲しい商品が，欲しい量品揃えされた 売場」を実現することに成功しているのである。

\section{3. おもてなし啓蒙者の開拓 : 現地企業との協業}

ファミリーマートは, 海外進出の基本フォー マットとして, 進出国の現地企業との合弁方式 を取っている（図表-7）。「小売はローカルなビ ジネス」といわれるが，各進出先の生活習慣な ど, 文化の違いを理解する必要がある。これは, おもてなしを提供する上でも同様である。日本 で喜ばれるサービスが，海外でも喜ばれるとは 限らない。そこで, 現地企業と合弁会社を設立 し，現地企業に主導権をゆだねることで，ビジ ネスの「最適化」を実現しているのである。し かし，現地に任せっぱなしにするのではなく， ファミリーマートも自ら出資し, 経営に参画し ている。そして，拈金を出すだけでなく，人材 を派遣し，ファミリーマートのノウハウを現地 へ移植している。こうすることで，ファミリー マートのクオリティを，海外でも実現できてい
るのである。この「委任」と「関与」の絶妙な バランスが，同社の海外展開の成功を支えてい るといっても過言ではない。

現地企業との提携は, 多様なメリットがある ものの，難しさもある。メリットとしては，例 えば，投資の分担ができるため投資リスクの回 避ができる，現地企業が持つ経営資源や，現地 の生活・食文化・商習慣・法規制を熟知した情 報力を活用できる，といった点があげられる。 しかし，彼らが，日本側の事業コンセプトや企 業理念を正しく理解し, 日本側が求める水準で の店舗運営を実現できる能力を持っていない と，事業がうまくいかない可能性もある。おも てなしといった，日本的な精神性を特徴として いる場合はなおさらである。直接出資を行って いてもそれが $50 \%$ 未満の場合，事業の成否は現 地企業次第となる。そのため, 提携先の選定は 非常に重要である。

ファミリーマートは, 合弁会社の提携先を 「パートナー」と捉えており，長期にわたって コンビニビジネスを一緒に育成できるかという ことを重視している。そのため, パートナー選 定にあたっては，ファミリーマートの企業理念 や事業戦略を理解・共有してもらえるか, 協業 できるか，対等に議論できるか，そして何より も信頼関係を築くことができるか，といった点 を考虑している。とくに，おもてなしなどの付 加価值で店舗の質を高めるといった戦略は，効 果が表れるまでには時間がかかるため（投資回 収までに10年かかることもありうる)，長期的 なビジネス戦略を取れる企業と組むことが大事 であるという。具体的には，次のようなパート ナー選定ポイントを持っている。

·人材面 
一ファミリーマート事業に専念できる人材

の派遣がある

一トップを支える幹部候補人材の派遣があ

る

・小売ビジネスへの理解

一経営者の顔が見える
ーファミリーマート事業への理解がある

一中期的視点に立った事業を行っている

・インフラ物流面

一全土での事業拠点配置が可能

・商品開発力

一中食やファストフードの開発力がある

図表一7 ファミリーマートの海外展開における事業スキーム

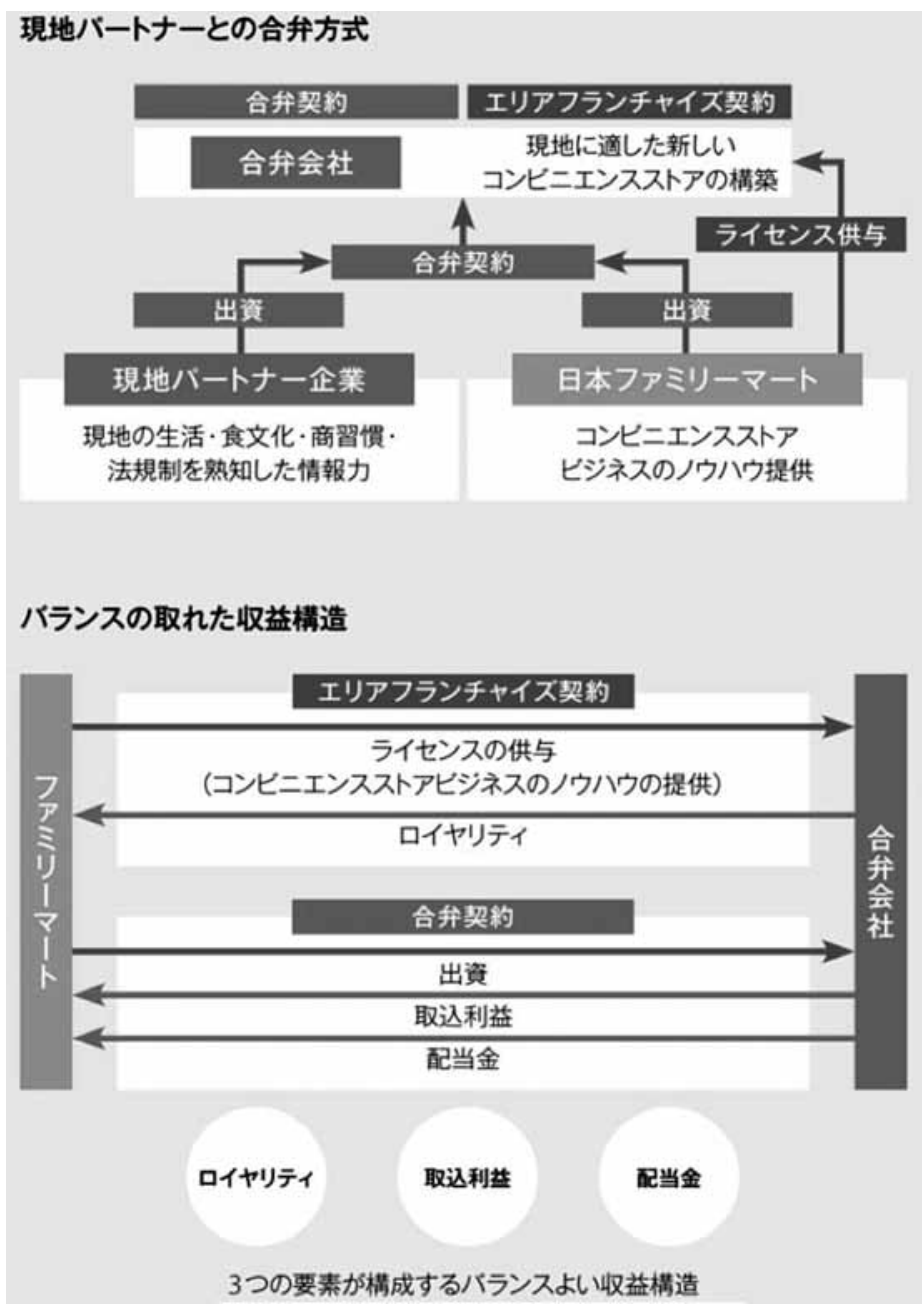

出典 : 株式会社ファミリーマート『アニュアルレポート 2014』p. 26 
・店舗開発力

一物件ネットワーク網を有する

ーフランチャイズビジネスモデルの重要性 への理解

- 財務力

一先行投資基準に耐え得る財務体質の保有 こうした基準で選んだパートナーと合弁会社 を設立し，「世界中どこのファミリーマートで も，お客さまを大切な家族の一員のような気持 ちでお迎えする」という共通の想いで，各国の 店づくりを行っているのである。

\section{4. おもてなし文化の醸成：グローバルブラン ディング}

ファミリーマートは，グローバルファミリー マートとしての一体感を醸成するため, グロー バルブランディングにも力を入れている。この グローバルブランディングは，おもてなし文化 の醸成のための活動と捉えることもできる。お もてなしを含むサービス・エクセレンスを維持 する上では，サービスのシステムを構築する だけでなく，そのサービス・システムを補強 する企業文化が必要といわれている（Frei \& Morris, 2012)。サービスは生産と消費が同時に 発生し, 保存ができないため, 一人ひとりの従 業員に，企業理念に沿った意思決定と行動が求 められる。そのようななか，企業文化は，個人 の意思決定を手引きし，また組織行動や態度の 土台となるのである。

ファミリーマートでは, グローバルで企業理 念や価值観を共有し，一つの企業文化を醸成 するために,さまざまな取り組みを行ってい る。その一つが，2003年から実施されている 「FamilyMart Summit」である。これは年に1
回，各社のトップが一同に会して行われるグ ローバルミーティングである。海外戦略の基本 方針決定を行うほか，各地域における事例の共 有や，トップ同士による意見交換をはじめとし たコミュニケーションなどを通じて，チェーン 全体の一体感を醉成している。また, グローバ ルチェーンとして躍進するブランド力を総合的 に高める場としての役割も担っている。

また 2012 年度には，世界共通のアクション ガイドライン（行動指針）として，グローバル ファミリーマート共通のスローガン「Welcome to the Family（ようこそ我が家へ。お帰りな さい。）が策定された（図表-8）。この共通し たファミリーマートの理念や価值観を世界中の ファミリーマートに浸透させたことで，国境を 越えたブランドイメージの統一を図ることが可 能となり，客が世界中どこのファミリーマート を利用しても，親しみが感じられる店づくりを 目指すことができるようになった。しかし岩崎 は，このスローガンが決定するまでの道のりは 険しかったという。日本のコンビニが置かれて いる状況と，例えば中国やインドネシアなどで のコンビニの状況は異なるため, ホスピタリ ティに関する世界共通の価值観を見出すのには 苦労したという。

グローバル展開となると考え方もいろいろ あって，なかなか共通項を見出すのは難し かったですね。

だけど，そういう中で，やっぱり共通して いるのは, チェーン名であるファミリー マートの「ファミリー」という部分。この 概念は，一緒かもしれないよね，というこ とで。そういう意見を出し合いながら， 
ファミリーとしてお客さまを迎えるという

ことはどういうことなのか, そういった視

点合わせを，段階を経てやってきたという

経緯があります。

こうして生まれた世界共通の行動指針は, ファミリーマートの企業理念をグローバルで浸 透させ，企業文化を醸成する上で一役買うよう になった。かつては, フランチャイズ・ビジネ スで一つの理念を共有するのは無理といわれて いたが, ファミリーマートではグローバルレベ ルで行動指針が重視されるようになった。山下 は, 行動指針の一番の効果は, アルバイトまで 含めた社員全員が自分の仕事に誇りを感じられ るようになったことだと述べている。

一番大きいのは, ファミリーマートのブラ ンドの中の一員なんだという誇りと, 自分 の行動がファミリーマートの看板に，大き な影響を与えるんだという責任感。(中略) それがいわば接客に現れたり，お客さまと の対話に現れたり，とするようになってく
るんだと思います。

今では，客とのやりとりはもちろんのこと，社 員同士のつき合い, ならびに取引先やビジネス・ パートナーとの交流を含めた，あらゆる行動に おいて企業理念や価值観が反映されるように心 がけられている。

\section{5. おもてなし人材の育成：現地人材の育成}

先に述べたように，ファミリーマートでは， おもてなしの標準化や脱属人化を進めている。 とはいえ，ストアスタッフの育成を意っている わけではない。「明るくスピーディーでホスピ タリティあふれる温かい接客」の提供に向けて, 現地人材の育成にも力を入れている。

ファミリーマートが，サービスに対する見解 の文化差で苦労した国の一つがべトナムであ る。ベトナムでは, ホスピタリティの概念があ まり発達しておらず，小売の店員が挨拶をする といったことや，客に笑顔を向けるといったこ とはなかった。どちらかというと, 小売が物を 売ってあげているという環境で, 客と小売の関

\section{図表一8ファミリーマートグローバルスローガン}

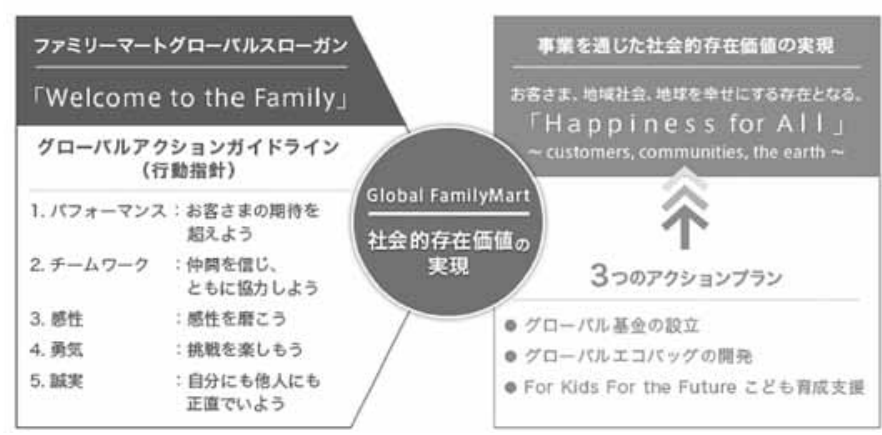

出典：株式会社ファミリーマート ホームページｈttps://www.family.co.jp/company/eco/special/03.html 
係は決して対等ではなかった。

そのようななか, ファミリーマートが日本流 の扮もてなしを展開するにあたっては，店長 やストアスタッフの教育にも苦労したという。 2009 年に, 1 号店の開店に向けて店長候補のト レーニングをしたところ，どんなサービスをす れば良いのか，最初はまったく分かってもらえ なかったという。彼らは，「挨拶する」「ありが とうございますと声をかける」といったことに, まったく理解を示さなかった。むしろ，「そん なにお客さまに声をかけると，うるさいと怒ら れます」などと, 反対された。

ファミリーマートは, ベトナム人がサービス の良し悪しを判断できないのは，彼らが良い サービスを体験したことがないためではないか と考えた。そこで, ベトナムのストアスタッフ をタイに連れて行き，1週間，ファミリーマー トのサービスを実体験させた。タイのファミ リーマートは1993年に1号店を開店しており,
日本流のおもてなしがすでに伝わっている国 だった。

ベトナムのストアスタッフは，そこで，客と して大切にされると嬉しくなるといったことを 自ら体験し，気持ちの良い接客で買い物をする 楽しみを理解した。その後は飲み込みも早く, すぐに拈もてなし精神でサービスを行うように なった。その後, 彼らはべトナムの新入社員を 指導する立場となり，おもてなしの伝道師的な 役割を担うようになった。結果, ベトナムのファ ミリーマートでは，ストアスタッフたちの感じ の良さが目立つようになった。今では，すれ違 うと笑顔で会釈してくれ，温かい接客で迎えて くれる。

2004 年に進出した中国でも，サービスといっ た概念が浸透していなかったため, 同様の苦労 があった。中国の場合には，1988年に進出し， 既に成功している台湾が，同じ中華圈で文化が 近いということで橋渡し役となっている。例え

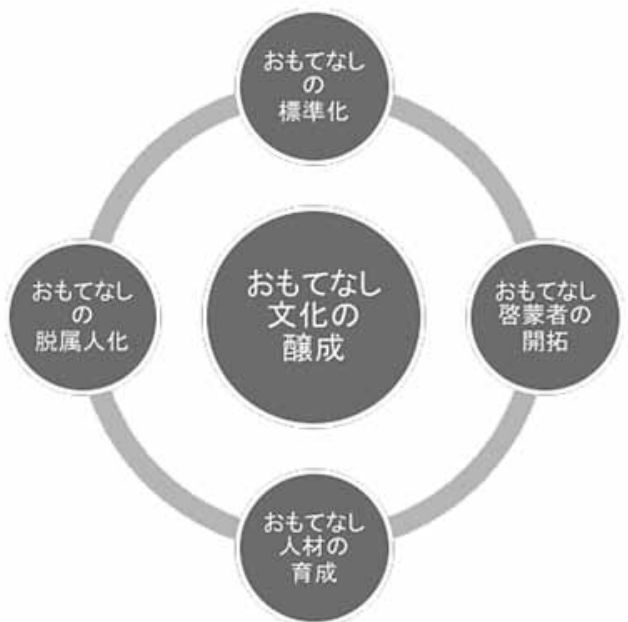

注：おもてなしは，サービス設計と企業文化の掛け算で実現される。この図では，外側にサービス設計が， そして内側にサービス設計を支える企業文化が表現されている。企業文化は，すべての組織行動や態 度の中心に存在するのである。 
ば，中国の幹部社員は，台湾ファミリーマート の代表的な店舗で研修を受けている。こういっ た派遣は，毎年2回，行われているという。ま た，中国ではエリアごとに研修センターを完備 し，接客に関する研修に力を入れているが，こ うした研修センターでも，台湾ファミリーマー トのスタッフがトレーナーを務めることで， ス ムーズなコミュニケーションが図れているとい う。中国のストアスタッフは，こうした研修を 通じて，ワンランク上の接客スタイルを身に着 けている。そして，この，地場のコンビニには ない接客サービスが，ファミリーマートの差別 化につながっているのである。

ファミリーマートでは, SQCの概念のもと, 客の入退店時に「いらっしゃいませ」「ありが とうございました，またお越しくださいませ」 と，お声掛けすることを徹底しているが， ベト ナムや中国ではこのような店頭挨拶の習慣がな いため，まずはこのことを理解してもらうこと から始めなければならないという。一見シンプ ルな挨拶の指導の苦労について，山下は次のよ うに語っている。

仕組みは，日本とまったく同じなんですよ ね。採用しますと，まず座学といいますか， レクチャーで概要を説明します。サービス がいかに大切かっていうことを説明するわ けです。で，店舗に入ったときにそれがで きるかどうか，ってところが大きくて。皆 さんやったことがないから，恥ずかしいん ですよね，声を出すってことが。まず笑顔 ができない。「ありがとうございました」っ ていうことができない。そんなのは㷣です から，もう何回も何回も，鏡を前にして練
習させるというのが徹底させてまして。で, 後は，できたらほめてあげる，というのを 基本にしていまして。(中略）店長がまず 見本を見せて，やらせてみて，できたら褒 める，この繰り返しです。(中略）こうあ るべきだってことを，まず吒き込むわけな んですけれども。どうしても䭾目だという 人はですね, 辞めて行くんでしょうけども， そこを通り抜けた人は，かなり強いスタッ フになっていきますよね。

海外の店舗展開を担うグローバル人材の 育成にさらに力をいれる目的で, 2014 年 3 月，ファミリーマートはタイに「FamilyMart Academy」(ファミリーマート・アカデミー) を設立した。現地法人トップ候補の管理職に加 え, 商品開発や物流整備を担当する専門家を育 てる。研修期間は 1 年から 1 年 6 力月で, 研修 者は現地の事情に即した商品開発や出店, 物流 システム整備などの実務に取り組む。タイの FamilyMart Academyは, ASEANの人材育成 の中心に位置付けられており，インドネシアや フィリピンで働く人材も対象としている。将来 的には，東アジアをカバーする同様の拠点を， 台湾に設ける予定だという。

\section{IV. おわりに}

本稿では, 日本流のおもてなしといった，海 外でビジネスを展開する上で競争優位性の要因 になる可能性を秘めつつも，文化や商習慣が異 なる環境で展開するのが難しい特性の海外展開 について, 海外にいち早く店舗展開を進め，ま たおもてなしを海外で差別化要因として活用し 
ているファミリーマートの事例を通じて，分析 を行った。おもてなしの海外展開を支えると考 えられる「おもてなしの標準化」「おもてなし の脱属人化」「おもてなし啓蒙者の開拓」「おも てなし文化の醸成」「おもてなし人材の育成」 といった5つの観点から分析を試みた。

Frei and Morriss (2012) は, 『Uncommon Service』のなかで, サービス・エクセレンス とはサービス設計と企業文化の掛け算で生まれ るものと述べている。ファミリーマートも，お もてなしを海外市場で競争優位性を築くための 要因として活用するために, サービス・システ ムを設計・構築し, 企業文化の浸透に力を入れ ているといえよう。サービス・システムとして は,「おもてなしの標準化」(マニュアル化),「お もてなしの脱属人化」(システム化),「扫もて なし啓蒙者の開拓」(現地企業との協業), そし て「おもてなし人材の育成」(現地人材の育成) があり，企業文化の浸透として「おもてなし文 化の醸成」（グローバルブランディング）があ ると整理できる(図表-9)。ファミリーマートは, マニュアル化やシステム化を進めることで， あ らゆる場所，そしてあらゆる人で，最低限のお もてなしを再現できるように工夫している。ま たマニュアル化やシステム化は，ストアスタッ フに余裕を与え，プラスアルファのおもてなし を実現することも可能としている。そして，お もてなしといった極めて日本的な精神を理解し てくれるパートナーと一緒に事業を海外で展開 し, 現地の人材がおもてなし精神でサービスを 行えるように教育しているのである。さらに, こうした活動を支えているのが，グローバルで 共有されている「私たちファミリーマートは, ホスピタリティあふれる行動を通じて，拈客さ
まに『気軽にこころの豊かさ』を提案し，快適 で楽しさあふれる生活に貢献します。」といっ た企業理念と価值観である。

こうした努力の結果, 元来サービスといった 概念が存在しなかった国でも，日本の店舗で見 られるような「ホスピタリティのある店づく り」が実現されるようになった。例えばインド ネシアでは，年中暑いため，店におしぼりを置 き，客が入ってきたときに渡すようになった。 またべトナムでは, 店に傘を置き, 雨が降って きたら自由に使って頂くようにした。ファミ リーマートの事例は，おもてなしが文化的に存 在しない市場でも再現可能であることを示して いる。

日本のサービス産業は，GDPの約 7 割を占め るにも関わらず，ドメスティック産業と呼ば れ，国際化が著しく遅れてきた。サービス産業

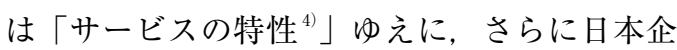
業は日本特有の価值観で育まれた企業文化ゆえ に，国際化が難しいと考えられてきた（大石， 2009)。そのようななか, ファミリーマートが 日本特有のおもてなしを武器に, 海外展開を進 めているという事実は, 海外展開が課題となっ ている日本のサービス産業にとって, 大きな七 ントとなろう。

謝辞

本稿の執筆にあたって, 株式会社ファミリー マートの上席執行役員・海外事業本部長補佐 (兼) 海外事業本部海外事業部長である山下 純一氏に，インタビュー並びに資料提供のご 協力を頂いた。また総合企画部マーケティン グ室長である岩崎浩氏にも, インタビューに ご協力頂いた。そしてインタビュー実施並び 
にデー夕整理に向け，大賀暁氏にご協力頂い た。ここに記して，心より感謝申し上げたい。

注

1） 2014 年 5 月に韓国の持分法適用関連会社である BGFretail Co., Ltd.の保有株式を売却し, 総数 16,184 店（2014 年 7 月 30 日時点）となった。

2) ファミリーマートでは, SST は人材育成のシステム にもなっている。初級・中級・上級の 3 段階に分か れており, 昇給・昇格と結びついている。

3）もっともこの特徵は, コンビニ業界においては, ファ ミリーマートに限ったものではないことを記してお く。しかしながら，おもてなしビジネスの拡大や海 外展開という視点で考えると, この特徴は重要であ るため, あえて記載した。

4）ここでは詳細な説明は省くが,「サービスの特性」 には主として「無形性」「生産と消費の同時性」「消 滅性」「異質性」の 4 つがあると考えられている。

\section{参考文献}

大石芳裕編 (2009).『日本企業のグローバル・マーケティ ング』白桃書房 .

五嶋正風・中村孝太郎 (2009) .「サービス価值共創と 日本の伝統的な『主客一体』:『拈もてなし』文化 における主客の関係とは」『研究・技術計画学会 · 年次学術大会講演要旨集』24, pp. 513-516.

鈴木智子・原田緑（2013）。資生堂：グローバル展開 一中国における『おもてなし』サービスの活用」『一 橋ビジネスレビュー』61(3), pp. 142-151.

山口英彦（2014）。「おもてなしで飯が食えるか?」 http://www.globis.jp/2729

Frei, F., \& Morriss, A. (2012). Uncommon service: How to win by putting customers at the core of your business. Boston: Harvard Business Review Press.

NHK（2010）「“おもてなし”で世界をねらえ」『クロー ズアップ現代』2010 年 7 月 26 日放送.

\section{参考資料}

「ファミリーマート：ナカショク文化伝道, 収益を味付 けアジアの屋台に『お弁当』で挑む」『日経ヴェ リタス』 2012 年 4 月 22 日, p.16.

「ファミリーマート社長兼 CEO 兼 COO : 上田準二」『週 刊ダイヤモンド』2009 年 1 月 31 日 , pp. 112-115.

『日経流通新聞』 2008 年 4 月 21 日, p.1.
『日経流通新聞』 2000 年 3 月 23 日, p.4..

\section{鈴木 智子（すずきさとこ）}

京都大学大学院 経営管理研究部 特定講師

一橋大学大学院国際企業戦略研究科修士 (MBA), 同 博士後期課程（DBA）修了。博士 (経営学)。専門は 消費者行動論, 国際マーケティング。

日本ロレアル (株), ボストン・コンサルティング・ グループなどを経て，2011 年より現職。

主要論文・著作 :

鈴木智子（2013）.「イノベーションの普及における 正当化とフレーミングの役割：『自分へのご裹美』消 費の事例から」白桃書房.

鈴木智子・竹村幸祐（2014）。「サービ ス業のグロー バル・ブランディングに関する再考：ユニバーサル． スタジオの事例から」『マーケティングジャーナル』 131, pp. 108-126.

鈴木智子・原田緑（2013）。「資生 堂：グローバル展 開一中国における『おもてなし』サービスの活用」『一 橋ビジネスレビュー』61(3), pp. 142-151.

Suzuki, S. \& Takemura, K. (2013). “Culture and social media: Exploration of differences between the U.S. and Japan.” In M. R. Olivas-Luján \& T. Bondarouk (Eds.), Advanced series in management, Vol. 11, pp.245-258. 